\title{
Silent angels the genetic and clinical aspects of Rett syndrome
}

\author{
Milczące anioły; aspekty genetyczne i obraz kliniczny zespołu Retta (Rett syndrome)
}

\author{
Ewelina Dziwota ${ }^{1}{ }_{\mathrm{ABDEF}}$, Urszula Fałkowska ${ }^{2}{ }_{\mathrm{BDEF}}$,

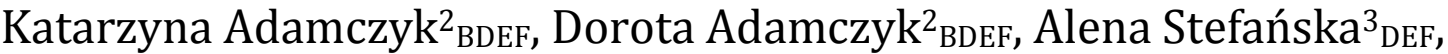 \\ Justyna Pawęzka ${ }^{1}$, Marcin Olajossy ${ }^{1} \mathrm{DE}$
}

\author{
1. Second Department of Psychiatry and Psychiatric Rehabilitation, Department of Psychiatry at the Medical \\ University of Lublin \\ 2. Students Scientific Society at the Second Department of Psychiatry and Psychiatric Rehabilitation \\ 3. Department of Clinical Psychology and Cardiology, Medical University, Lublin
}

\begin{abstract}
Rett syndrome is a neurodevelopmental genetic disorder and, because of some behavioral characteristics, individuals affected by the disease are known as silent angels. Girls with Rett syndrome perform stereotyped movements, they have learning difficulties, their reaction time is prolonged, and they seem alienated in the environment. These children require constant pediatric, neurological and orthopedic care. In the treatment of Rett syndrome physical therapy, music therapy, hydrotherapy, hippotherapy, behavioral methods, speech therapy and diet, are also used. In turn, psychological therapy of the syndrome is based on the sensory integration method, using two or more senses simultaneously. In $80 \%$ of cases, the syndrome is related to mutations of the MECP2 gene, located on chromosome $\mathrm{X}$. The pathogenesis of Rett syndrome is caused by the occurrence of a non-functional MeCP2 protein, which is a transcription factor of many genes, i.e. Bdnf, mef2c, Sgk1, Uqcrc1. Abnormal expression of these genes reveals a characteristic disease phenotype. Clinical symptoms relate mainly to the nervous, respiratory, skeletal and gastrointestinal systems. Currently causal treatment is not possible. However, researchers are developing methods by which, perhaps in the near future, it will be possible to eliminate the mutations in the $M E C P 2$ gene, and this will give a chance to the patient for normal functioning.

The paper presents the etiology and pathogenesis of the disease, genetic, clinical, pharmacological aspects and other forms of Rett syndrome treatment.
\end{abstract}

Keywords: Rett syndrome, ASD, MECP2 gene, MeCP2 protein

\section{Streszczenie}

Zespół Retta jest schorzeniem neurorozwojowym uwarunkowanym genetycznie, a osoby nim dotknięte ze względu na niektóre cechy behawioralne nazywane są Milczącymi Aniołami. Dziewczynki z zespołem Retta wykonują ruchy stereotypowe, mają problemy z uczeniem się, ich czas reakcji jest wydłużony, a w stosunku do otoczenia - sprawiają wrażenie wyalienowanych, wyobcowanych. Dzieci te wymagają stałej opieki pediatrycznej, neurologicznej i ortopedycznej. W terapii zespołu Retta stosuje się także fizykoterapię, muzykoterapię, hydroterapię, hipoterapię, metody behawioralne, logopedię oraz dietę. Z kolei terapia psychologiczna zespołu opiera się na metodzie integracji sensorycznej, wykorzystującej dwa lub więcej zmysłów jednocześnie. W 80\% przypadków zespół jest związany z mutacjami genu MECP2, zlokalizowanym na chromosomie X. Patogeneza zespołu Retta jest spowodowana powstaniem niefunkcjonalnego białka MeCP2, będącego czynnikiem transkrypcyjnym wielu genów, tj. Bdnf, mef2c, Sgk1, Uqcrc1. Nieprawidłowa ekspresja tych genów objawia się charakterystycznym fenotypem chorobowym. Objawy kliniczne dotyczą głównie układu nerwowego, oddechowego, kostno-szkieletowego i pokarmowego. Obecnie nie jest możliwe leczenie przyczynowe. Jednak naukowcy opracowują metody, dzięki którym, być może w niedalekiej przyszłości, uda się wyeliminować mutacje w genie MECP2, a to zapewni szansę chorym na normalne funkcjonowanie.

W pracy zaprezentowano etiologię i patogenezę schorzenia, aspekty genetyczne, obraz kliniczny, farmakoterapię i inne formy leczenia zespołu Retta.

Słowa kluczowe: zespół Retta, ASD, gen MECP2, białko MeCP2

\section{Introduction}

Rett syndrome is a genetic neurodevelopmental disorder characterized by a progressive degeneration of brain tissue. It is also one of the most common causes of intellectual disability. The incidence of the syndrome is determined at 1: 10000 - 22000 women. Due to the varied clinical picture of the disease, three forms of Rett syndrome are distinguished in literature: the classic, 
atypical form and the form with preserved speech. For the first time the syndrome was described by Austrian physician Andreas Rett in 1966.

\section{Etiology and pathogenesis of the disorder}

According to the contemporary literature, due to the coexistence of genetic, environmental, as well as factors affecting non-genetic inheritance (mitochondrial), there is a mutation of the MECP2 gene. Diverse phenotype of the syndrome depends on the correlation of these factors and is associated with different mutations of the MECP2 gene [1].

Based on published in literature research results it can be concluded that in $80 \%$ of cases, the Rett syndrome is associated with mutations in the MECP2 gene (methyl CpG-binding protein 2) (OMIM * 300005) [3], linked to chromosome Xq28. This is a gene encoding a protein with a transcriptional repressor function [2]. Mutation in the MECP2 gene in $70 \%$ concerns the conversion of cytosine to thymine at exon 3 and 4 , of eight $\mathrm{CpG}$ islands as a result of deamination reaction. Such mutations include T158M, R106W, R133C, R255X, R270X, R294X, R306C, and the most common is R168X [11]. R133C mutation leads to a milder form of Rett syndrome [17] [18] [19], while the R270X mutation is associated with increased mortality [20].

In addition, the MECP2 gene contains a long noncoding portion, long intron sequences. Additional sequences are the basis for synthesizing a functional nonencoding RNA, which controls the phase of transcripts splicing. In turn, as a result of alternative splicing of the primary transcript two isoforms (MECP2 e1, e2-MECP2) are formed [1]. This structure of the MECP2 gene allows forming of more than one mRNA molecule, which is a source of protein variability. It is believed that the molecules that are produced on the basis of introns may play an important role in the development of neurological or psychological disorders [12].

Initially Rett syndrome was thought to occur only in women, but this was refuted, along with the identification of the classical form of the syndrome in a boy [27]. Rett syndrome affects almost exclusively girls, in whom, among other things, the classic form of the syndrome is observed, atypical varieties: a form resembling Angelman syndrome [21] [22], autism, mild intellectual disability, intellectual disability with seizures and learning difficulties [23] [24], or a form without explicit behavioral changes.

The loss of the MECP2 gene function influences in a different way females and males [16]. MECP2 mutations that cause classical form of the syndrome in women usually lead to neonatal encephalopathy of males and death in the first year of life. In addition, the same dysfunctions may cause Klinefelter's syndrome $(47, \mathrm{XXY})$ or somatic mosaicism. Finally, some MECP2 mutations that do not cause visible changes in women, can cause all kinds of diseases in men: bipolar disorder, intellectual disability, impaired motor skills [25], adolescent schizophrenia [26]. According to research by Chahrour M. et al., overexpression of the MECP2 gene in males may result in nonspecific, severe mental retardation. Thus, neurodevelopmental disorders are due to loss of MeCP2 function, however, the increase in the MeCP2 protein concentration can also be detrimental to the nervous system [16].

The causes of Rett syndrome, according to the results of modern research, are mainly de novo mutations originating primarily on paternal chromosome [1]. There are also familial forms of Rett syndrome caused by:

- maternal germline mosaic [4], as well as rarer paternal germline mosaic of [8]. This means that abnormal cell lines exist in the gonads, while the blood cells karyotype is normal. This type of mosaic pattern is likely to occur in couples whose children have the same chromosomal aberration.

- targeted, non-selective inactivation of the maternal X chromosome, and less frequently occurring selective inactivation [9].

The first line contains cells with the active $\mathrm{X}$ chromosome and the mutated MECP2 gene formed during inactivation of the partner X-chromosome. The second line contains cells with the active X-chromosome and nonmutated MECP2 gene. This contributes to somatic mosaic pattern of cells in girls with Rett syndrome. In most cases there is a random pattern of the X-chromosome inactivation of a pair of homologous X-chromosomes.

Selective inactivation is not frequently occurring disorder. Depending on the preferred X- chromosome, phenotypic variability can be observed in girls with Rett syndrome. Monozygotic twins having a diverse course of the disease can exemplify this [14]. In addition, studies of Young I., Zoghbi H. Y., indicate the relationship between the degree of selectivity in the X- chromosome inactivation and the type of clinical symptoms and their severity on the example of transgenic mice [15].

According to research by Villard L. et al., there are cases in which the Rett syndrome phenotype occurs without mutations in the MECP2 gene, and includes a total selective form of inheritance of X-chromosome inactivation (XCI) [10].

Another gene involved in the etiopathogenesis of Rett syndrome is CDKL5 (STK9). It is a missense mutation and splicing mutation in the gene (OMIM * 300203) [3], which is located in the locus Xp22, and also encodes a cyclin-dependent kinase like 5), also known as serine / threonine protein kinase 9. According to the references, the MECP2 and CDKL5 genes participate in the same signaling pathway and are capable of autophosphorylation [13]. Most of the mutations in CDKL5 gene occur in women and they are only occasionally found in men. As a re- 
sult of this mutation, Rett syndrome phenotype is formed, called Hanefeld subtype [1]. Infantile spasms occurring already in the neonatal period are characteristic for this subtype. There is also accompanying epilepsy and a severe mental retardation.

Based on published studies, cytogenetic changes such as a balanced de novo translocation $\mathrm{t}(2 ; 14)(\mathrm{p} 22 ; \mathrm{q} 12)$, together with a neighbouring $720 \mathrm{~kb}$ inversion in a region of the breaking point of chromosome 14q12, lead to damage to the FOXG1 gene (Forkhead BoxG1) (OMIM +164874)[3] in a terminal 5 'end. This gene is responsible for the alternative splicing of the primary transcript into variant protein. In the literature, there has been reported a case of a girl with mental retardation, agenesis of the corpus callosum and microcephaly. After two weeks from the birth, large spasticity of muscles occurred in her. However, the acquired microcephaly was noticed at the age of six months, when she did not lift her head yet. Moreover, at the age of seven, quadriparesis occurred, the patient could not walk independently, sit or speak, seizures developed [5]. In two other unrelated girls with acquired microcephaly, motor stereotypy and delayed mental development, two different heterozygous mutations of FOXG1 gene were also identified [6]. These studies indicate that mutations in the FOXG1 gene may contribute to the formation of a phenotype characteristic of Rett syndrome.

In the literature, as the etiologic agent, microdeletions (nucleotides 1030 and 1207), and microduplications of regions critical to the Rett syndrome, are reported [11]. The microdeletions of MEF2C gene (Myocytes-specific enhancer factor-2 / Mads Box Transcription enhancer factor 2, PolyPeptide c) (OMIM * 600662) [3] will decrease the concentration of MeCP2 and CDKL5 protein. This protein is responsible for the programming of early neuronal differentiation, as well as an appropriate distribution in the neocortex. The literature gives four cases of mutations of this gene in patients with atypical form of Rett syndrome.

It is possible that mutations of NTNG1 gene (G1) (OMIM * 608818) [3], are also responsible for the formation of syndrome-specific phenotype. Borg I. et al., described the case of a girl, in whom chromosomal translocation between chromosomes 1 and 7 was identified. The study showed that the NTNG1gene continuity on chromosome 1 was disrupted, while the continuity of genes on chromosome 7 was preserved [7]. According to references, the netrin, showing expression, participates in the development of the brain and therefore there are assumptions regarding its participation in the development of Rett syndrome.

Contrary to earlier theories that considered the $\mathrm{MeCP} 2$ protein as universal repressor of transcription, Chahrour and colleagues demonstrated that MeCP2 more often acts as an activator of target genes. Moreover, the MeCP2 protein, to a varying degree, may activate the expression of a given gene. It depends on the methylation status of the gene promoter subordinate to MeCP2 protein. If it is less methylated, then MeCP2 acts as an expression activator. However, it is a repressor if methylation of the promoter is stronger. Thus, according to the results of the above studies, MeCP2 protein must be considered as a factor controlling expression of the given genes.

The MeCP2 protein also plays a key role in synaptogenesis. Together with CREB1, it is involved in maintaining nerve plasticity. MeCP2 induces CREB1activity, CREB1, in turn, inhibits the synthesis of the MeCP2 protein. These proteins are phosphorylated during activation of neurons and may affect genes activated during the formation of synapses. As a result of mutation, leading to a deficiency in $\mathrm{MeCP} 2$, the number of activated synapses is reduced.

According to references, in girls with Rett syndrome changes pertaining to reduced size of the nerve cells and the reduced dendritic spines density, have been observed. In addition, there is evidence that the decline in the density of dendritic spines and lower presynaptic protein synthesis in the hippocampus (in the mouse model) is caused by abnormal function of MeCP2.

Breathing disorders occurring in the Rett syndrome can also be caused by a deficiency of the MeCP2 protein, determining the abnormal development of the nervous system in patients. It is possible that this is due to the weakening of the noradrenergic system, brain stem immaturity or malfunctioning of the cerebral cortex. Furthermore, studies in animals have demonstrated that with age there is a reduction in BDNF protein synthesis. This protein is a regulator of synaptic activity of the autonomic nervous system in the brain stem and cranial sensory ganglia. In addition, BDNF protects against brain ischemia, because it is one of the factors responsive to oxidative stress. Therefore, the MeCP 2 protein by acting on the bdnf gene, plays a very important role in the circulatory and respiratory homeostasis.

In addition, the MeCP2 protein was proved to be is involved in body's response to stress, because it increases the expression of genes responsible for the regulation of the glucorticosteroids synthesis. Among others, McGill et al. investigated the physiological reaction in response to stress in mice with a Mecp2308 mutation. These studies showed an increase in the concentration of corticosterone and $\mathrm{Crh}$ gene expression, caused by an abnormality of the MeCP2 protein. In response to stress in mice devoid of the Mecp2 gene caused by altered sim1gene expression, elevated levels of leptin, melanocortin, neuropeptide $\mathrm{Y}$ and arc. protein, an increase in appetite was observed. It is possible that the development of obesity in girls with Rett syndrome has the same pathological mechanism. 
MeCP2 protein also regulates directly the expression of many genes, i.e. $B d n f$, mef2c, Sgk1, Uqcrc1 or DLX5, etc. The protein encoded by the Bdnf gene, brain-derived growth factor, controls the maturation of neurons, is responsible for neuronal plasticity and breathing function. In contrast, the $S g k 1$ gene product is a regulator of glucocorticoid pathway to hypothalamus-pituitary axis. In turn, the protein encoded by the mef2c gene is a myocyte polypeptide transcription factor. The Uqcrc1 and DLX5 genes respectively encode mitochondrial regulator of respiratory response and neuronal transcription factor. The products of these genes are of great functional importance in the body and are responsible for the characteristic phenotype of the syndrome. It is extremely important to identify those products, because it influences the decision regarding the type of implemented therapy in patients with Rett syndrome [1].

\section{Clinical overview/presentation/characteristics}

Rett syndrome can occur without mutation of the MECP2 or may coexist with them; therefore it is primarily the clinical diagnosis. This syndrome consists of a number of co-existing symptoms of different systems. Disturbances occurring to the nervous system, gastrointestinal tract and skeletal disorders prevent the normal development of children. In turn, the characteristics of the behavior of children with Rett syndrome made the girls affected by this genetic disorder called Silent Angels. Girls with Rett syndrome perform stereotyped movements, their reaction time is increased, and in relation to the environment, they are characterized by alienation. Children with the syndrome are often diagnosed as mentally deficient, but these diagnoses are challenged. Because conventional intelligence tests are usually based on the language skills, they also require the use of hands, the two weakest features of people with Rett syndrome [54].

According to the references, in patients with Rett syndrome mainly changes in the locomotor system are observed. Osteoporosis and changes in the spine and feet are the primary concern of the people affected by RTT. Thus, according to the results of studies published in the literature, scoliosis occurs in $100 \%$ of non-ambulatory and $36-64 \%$ of ambulatory girls. It causes not only pain or disorders of balance, but also respiratory disorders, i.e. hyperventilation, apnea, breath holding or forced exhalation and letting out saliva [45]. Another clinical symptom of Rett syndrome is small feet in girls, also the feet are cold, marbled and hypotrophic. Moreover, the decrease in body weight is characteristic (BMI - 17.5) and a slower growth rate occurring in $85-90 \%$ of individuals with Rett syndrome, progressive with age [54].

Also atrioventricular and intraventricular conduction disturbances, are typical i.e. tachycardia, prolonged QT interval, sinus bradycardia and abnormal $\mathrm{T}$ wave. Rett syndrome is also characterized by nonspecific malabsorption disorders and those associated with gastro-oesophageal reflux disease [52]. In Rett syndrome the seizures are a serious problem, especially the complex partial and generalized tonic-clonic and abnormalities in EEG pattern. They occur in $85-50 \%$ of women [53] after puberty and tend to decrease in severity in adulthood. When studying a group of 91 people with the RTT, decreased mood level was found, but in comparison with control group, the differences were not statistically significant. In contrast, episodes of self-harm were less frequent in Rett syndrome than in the control group [49].

Due to the varied clinical features of the disease in the literature three forms of Rett syndrome are described: classical form, atypical form, and the form with preserved speech [55]. Classical form of the Rett syndrom is characterized by four stages of the disease, and the spectrum of clinical symtoms varies with age. Infants initially develop like their healthy peers [56]; they are often quiet, cry a little and sleep a lot. The first noticeable symptoms usually appear at 6-18 months of age. During this period slower growth in head circumference is also observed, the child shows less interest in toys, rarely makes eye contact, sometimes there is also hypotonia of trunkal muscles $[48,54]$. This is the first phase of the classic form of Rett syndrome.

Then the period of stagnation and regression comes and the period of the child development inhibition. It usually lasts from 1 to 4 years of age [57]. Then the child so far normally developing, from day to day loses contact with the environment, becomes apathetic, quiet, not interested in toys. The child loses basic skills, called milestones, which were acquired in infancy. Sitting, walking and manual skills (e.g. grabbing) gradually disappear [58].

Loss of control over their own body and mind usually leads to frustration, anger, sadness, fear and astonishment, as well as a sense of loss. Then the child withdraws emotionally, it becomes apathetic [54].

Purposeful hand movements are replaced by repetitive stereotypical movements, i.e. clapping hands, movements like hand-washing, washing, wringing, touching the face and head, inserting into the mouth etc. It is usually one of the first alarming symptoms inducing parents to visit a specialist. According to references, the stereotyped movements are one of the most important diagnostic criteria of the syndrome.

In many children with the syndrome in the second phase of the disease abnormal breathing also appear breath-holding or air-swallowing, hyperventilation, and bruxism, which disappear during sleep. There are also disturbances in sleep-awake rhythm, night attacks of unjustified screaming or laughing [49]. Emotional lability is associated with physical ailments such as constipation, hyperventilation, bowel pain, excess stimuli and tempera- 
ture change [54]. Literature indicates the existence of periods of excessive stimulation of people with Rett syndrome, which can be an expression of negative emotions or unaccepted changes in the environment [48]. In turn, hyperactivity and impulsivity according to research by Cianfaglione R. et al., are not characteristic for the syndrome.

Within a few weeks or months regression in motor skills occurs. In studies of Nomura Y. and M. Segawa in a group of 130 individuals with RTT, 83.3\% demonstrated gate ataxia, $63.6 \%$ - delay in crawling, $42 \%$ - delay in sitting down. In the second phase of the disease, muscular hypertonia was also present. Often the first seizures are present, which can be a symptom of epilepsy [48]. Social contacts are deteriorating and autistic behaviors and impaired response to pain are present, these symptoms are often mistaken for autism. A significant loss of emotional bond between the child and the parents is noticeable. Even communication with the child using gestures and eyesight is getting worse, so the contact is very difficult. At the end of this stage, there is a partial recovery of emotional balance, which involves, among other things calmer disposition of the child [54].

The third phase of the disease, called the stage of apparent stagnation lasts from about 2 - 10 years of age. The motor problems and epilepsy are still present. Motor skills of the patient constantly deteriorates (apraxia or ataxia), increase in muscle tone is observable. There are problems with the skeletal system (scoliosis, deformity of the ankles and feet). In spite of these problems, a noticeable improvement of social and emotional contacts of the child can be seen. The child becomes calmer and less tearful. At this stage, there is a strong need to explore the world [48]. Unfortunately, over time, the children again manifest autistic traits, i.e. hypersensitivity to sounds, they lose the ability to express emotions and are unable to maintain eye contact [58].

Adults who are in the final - the fourth stage of the disease, have problems with ambulation. The atrophy of muscles, spasticity and worsening of scoliosis are characteristic of this phase. Most of the women, who could ambulate to that point, lose that skill. Although seizures and hand-wringing are less frequent. In addition, the improvement of emotional and eye contact occurs [48]. According to research by Lane J. et al., people characterized by a worse clinical condition, usually have a better psychosocial functioning [51]. On the other hand, in the late stage of the disease in people with Rett syndrome features of parkinsonism and panic disorder may be present [59].

Whereas the atypical form of Rett syndrome is characterized by a lack of period of normal development. It is much more severe than the classical form [60]. The delay is usually noticed soon after the birth of a child so the phase of the normal development of the child is not pre- sent, just as there is no phase of regression [48]. In this form, infantile spasms and congenital muscular hypotonia are characteristic.

In turn, the third form of Rett syndrome - the form with preserved speech - occurs in 1-4\% of people with Rett syndrome and is distinguished by late onset of the disease [60]. Gradual regression is characteristic, which begins after the third year of life [54]. According to Marschik P. et al., among children with preserved speech, there are also social and communicative disorders that are present even before the period of regression [50].

Basic diagnostic criteria for Rett syndrome.

According to the existing currently ICD-10, the diagnosis of Rett syndrome is based on the following criteria:

- Apparently normal pre- and perinatal history

- Psychomotor development normal during the first 5 months or may be delayed from birth

- Normal head circumference at birth. Postnatal deceleration of head growth between 0.5 - 4 years.

- Loss of purposeful hand skills between 6-30 months. Instead, there are stereotypic hand movements (e.g. hand wringing, hand washing, clapping, patting, or other hand automatisms).

- Evolving social withdrawal, communication dysfunction, loss of acquired speech, cognitive impairment.

\section{Pharmacotherapy}

In the past few years, there have been reports concerning the function of MeCP2, as well as the consequences of the loss of the protein, and the research works were commenced on the potential therapeutic strategies of the Rett syndrome [28-33]. These include, among others: molecular genetic methods, activation of "the wild-type" allele on the inactive X-chromosome and pharmacological methods being at the stage of clinical investigations, focused on restoring the inhibitory-stimulating balance of the nervous system. The purpose of these strategies is primarily the normalization of the $M E C P 2$ gene expression without affecting the products of other genes. Both in the case of gene therapy and in the case of activation of "the wild-type" allele on the inactive X-chromosome, it is important to achieve the production in the cell of sufficient quantities of MeCP2 protein whit simultaneous suppression of MECP2 overexpression.

\section{Activation of MECP2 on inactive X chromosome}

According to research studies published in the literature, most mutations lead to production of nonfunctional MeCP2 protein. Thus, reactivation of "the wildtype" on the inactive $\mathrm{X}$ in this approach may be useful for treating many forms of Rett syndrome. In addition, Meng, L.et al. in their research demonstrated therapeutic value 
of reactivation of disease genes in mice with Angelman Syndrome. In this study, a dormant gene Ube3a (not damaged) was pharmacologically activated to replace the mutated gene Ube3a [34] [35]. In addition, a reporter gene, which is a gene visualizing Mecp2-GFP is a valuable tool to assess the activation of MeCP2 allele. The results of the studies confirm that there is a possibility of reactivation of the entire inactive X (XI). Recent works have shown that the loss of the protein hormone, Stanniocalcin 1 (STC1) disrupts the process of silencing the expression of genes linked to the $\mathrm{X}$ chromosome, including Mecp2. Thus, this approach may seem less attractive [36].

On the other hand, research conducted by Adrian Bird from the University of Edinburgh, demonstrate that the application of the MeCP2 protein to mice with a mutant gene, results in reversal of changes in the damaged brain, thereby restoring of the proper functioning of organism. In view of the above research on the development of therapies of defective MECP2 protein, there is a chance to eliminate the symptoms of the disease also in children and adults with Rett syndrome [48].

\section{Gene therapy}

Another method aimed at restoring the function of MeCP2 involves replacing defective gene or correcting defective genes. According to recent studies, by using a recombinant adenoviral vector (AAV9), gene transfer throughout the nervous system is possible [37] [38] [39]. In the mouse model of Rett syndrome, lacking the MECP2 gene after intravenous administration of the vector AAV9 / MECP2, there was a partial behavioral and phenotype normalization and the extension of life [40], [41]. The challenge of gene therapy is therefore to provide MECP2 in a narrow range, i.e. therapeutic range without causing harmful overexpression. Although the vector provides MECP2 to the brain, there comes to approx. 100-fold higher gene transfer in the liver, which is toxic [40].

\section{Therapeutic objectives}

There are carried out preclinical studies on potential drugs that may be effective in alleviating specific symptoms in patients with Rett syndrome. These drugs have been divided into three categories, including:

- Modification of noradrenergic, serotonergic, glutamatergic, GABAergic and cholinergic neurotransmission;

- Growth factors: brain derived neurotrophic factor (BDNF) and insulin-like growth factor 1 (IGF-1);

- Metabolic pathways, including the cholesterol biosynthesis pathway and mitochondrial pathways [28] [29] [31] [44]

In addition, there are reports from several laboratories that respiratory distress in the mouse model of Rett syndrome can be significantly improved by modifying the glutamate, GABAergic, noradrenergic, serotonergic neurotransmitters [45] [46].

The researchers are close to understanding the basic biology of MeCP2 and there are more and more examples of actions that improve or reverse symptoms in mouse models of Rett syndrome.

\section{Other forms of Rett syndrome treatment}

On the example of the results of many studies on the treatment of generalized developmental disorders (including Rett syndrome), early intervention and long-term individual therapy are recommended. In most western countries the law requires implementation of an appropriate plan of education for all children, including children with special needs. Under this program often speech therapy, physical therapy, occupational therapy or other forms of therapy are included additionally [53].

Clinical symptoms of Rett syndrome are very complex. In the first year of life Rett syndrome is most often mistaken for cerebral palsy, later with autism. Because the early stages of development of Rett syndrome do not reveal all the characteristic symptoms of the disorder, many times an incorrect diagnosis of disease entity may occur. Pediatrics plays a crucial role in the early diagnosis of Rett syndrome, as the rapid diagnosis of the child suspected of having the disorder is important.

Professional informing parents about the diagnosis is extremely important. Providing reliable information in order to broaden their knowledge about the disease and providing specific guidance where they can seek help [48]. The patient should be referred to the diagnostic team, which will determine his/her physical, mental and emotional development. Thus, the term "early intervention" includes the child's original diagnosis, therapy and support of the parents. Further, it comprises multidisciplinary care, with the aim of supporting the child's development and the prevention of the appearance of secondary life dysfunctions. In the treatment of Rett syndrome physical therapy, music therapy, hydrotherapy, hippotherapy, behavioral methods, speech therapy as well as a specialist diet are used.

Children with the Rett syndrome require constant pediatric, neurological and orthopedic care. In monitoring of the course of Rett syndrome, somatic and psychomotor development, nutritional status, motor skills and interpersonal contacts in the environment should be monitored. Particular emphasis is placed on physical rehabilitation, which includes general-development exercises, because these individuals are faced with a whole range of problems, starting from orthopedic and neurological difficulties. Overcoming the limitations associated with them is a very difficult task for someone with Rett syn- 
drome and their families. Therefore, working with a physiotherapist can improve efficiency and thus reduce the negative consequences of the lack of physical activity of the child [53].

On the other hand music therapy, which utilizes the potentially hidden skills of the individuals with Rett syndrome, gives them the opportunity to express their emotions and feelings, thereby fosters interpersonal communication. Andreas Rett already noticed great potential in music, allowing penetrating the barrier of disability of people with Rett syndrome. According to the current state of knowledge, music therapy improves motor skills and reduces hand-wringing. This method contributes to developing articulation, improves concentration and eye contact and has a positive impact on the development of emotional communication.

Most people with Rett syndrome have difficulty with the spoken language, but it is believed that their ability to understand language is much higher than the ability to speak [53]. Girls with Rett syndrome have big problems in establishing contacts with the environment. Most of them do not communicate through speech, but the gestures and facial expressions. Communication is made possible by the introduction of alternative, even the simplest forms of communication, e.g. images, pictograms or the "yes-no system". Functional communication training (FCT) is a good example [51], also a program based on the Piaget theory of development with elements Doman-Delacato method. The program includes alternative communication using PCS symbols [48].

On the other hand, manual functions are aided by various forms of occupational therapy. These patients have impaired cognitive functions, are not able to perform precise movements, because of apraxia. Individuals with RTT have difficulty in performing activities of daily living (eating, self-service), have disrupted movement planning, because they need more time to complete the ordered task. The therapist can help a person with Rett syndrome, using the method of "sensory integration", combining information from receptors of all the senses (touch, rocking, etc.) needed for the deliberate and effective action.

Hydrotherapy is helpful in reducing spasticity. A person with Rett syndrome can do things in water which are not possible while being on land. The patient is able to move easily and freely in water without fear of falling. In addition, hydrotherapy gives the child a chance to make more satisfying relationships with their peers $[48,53]$.

The effectiveness of therapy is determined, among other things by cooperation with parents of patients facing the necessity to meet the diverse challenges such as loss of child's subsequent skills. Families should be supported in making informed decisions about the use of alternative methods of treatment, rehabilitation, surgical interventions, the choice of professionals, education [53]. They should be instructed how to express emotions, be supported in the creation of a strong emotional bond with the child. Due to the volatile nature of the RTT syndrome, the therapeutic measures must be flexible, adapted to the situation and individual needs. The aim of the intervention carried out by therapists is primarily to achieve the best level of performance and the highest quality of life for individuals with Rett syndrome [53].

\section{Wprowadzenie}

Zespół Retta to neurorozwojowe schorzenie genetyczne, charakteryzujące się postępującym zwyrodnieniem tkanki mózgowej. Jest również jedną z najczęstszych przyczyn niepełnosprawności intelektualnej. Częstość występowania zespołu określa się 1 : 10000 22000 kobiet. Z uwagi na zróżnicowany obraz kliniczny schorzenia w literaturze przedmiotu wyróżnia się trzy postacie zespołu Retta: postać klasyczną, nietypową oraz postać z zachowaną mową. Po raz pierwszy zespół został opisany przez austriackiego lekarza Andreasa Retta w 1966 roku.

\section{Etiologia i patogeneza schorzenia}

Zgodnie ze współczesnym piśmiennictwem, na skutek współwystępowania czynników genetycznych, środowiskowych, jak również czynników wpływających na dziedziczenie pozagenowe (mitochondrialne) dochodzi do mutacji genu MECP2. Zróżnicowany fenotyp zespołu zależny jest od korelacji tych czynników oraz związany jest z odmiennymi mutacjami genu MECP2 [1].

$\mathrm{Na}$ podstawie opublikowanych $\mathrm{w}$ literaturze wyników badań można stwierdzić, że w 80\% przypadków zespół Retta jest związany z mutacjami genu MECP2 (methyl-CpG binding protein 2)(OMIM*300005) [3], zlokalizowanym na chromosomie Xq28. Jest to gen kodujący białko o funkcji represora transkrypcji [2]. Mutacja genu MECP2 w 70\% dotyczy zamiany cytozyny na tyminę w eksonie 3 i 4, w ośmiu wyspach CpG w wyniku reakcji deaminacji. Takimi mutacjami są: T158M, R106W, R133C, R255X, R270X, R294X, R306C, oraz najczęściej występująca R168X [11]. Mutacja R133C doprowadza do łagodniejszej postaci zespołu Retta[17] [18] [19], podczas gdy mutacja R270X jest związana ze zwiększoną śmiertelnością [20].

Ponadto gen MECP2 zawiera długą część niekodującą, długie sekwencje intronów. Dodatkowe 
sekwencje stanowią podstawę do syntezowania funkcjonalnego, niekodującego RNA, który kontroluje etap składania transkryptów. Z kolei w wyniku alternatywnego składania pierwotnego transkryptu powstają dwie izoformy (MECP2-e1, MECP2-e2) [1]. Taka struktura genu MECP2 umożliwia powstanie więcej niż jednej cząsteczki mRNA, co stanowi źródło zmienności białek. Istnieją przypuszczenia, że cząsteczki, które wytwarzają się na podstawie intronów mogą odgrywać istotną rolę $\mathrm{w}$ powstawaniu zaburzeń neurologicznych czy psychicznych [12].

Początkowo sądzono, że zespół Retta występuje jedynie u kobiet, jednak zostało to obalone wraz z identyfikacją klasycznej postaci zespołu u chłopca [27]. Zespół Retta dotyka prawie wyłącznie dziewczynki, u których obserwuje się m.in. klasyczną postać zespołu, odmiany atypowe: postać przypominającą zespół Angelmana [21] [22], autyzm, łagodną niepełnosprawność intelektualną, niepełnosprawność intelektualną z napadami padaczkowymi oraz trudności w nauce [23] [24], bądź postać bez wyraźnych zmian behawioralnych.

Utrata funkcji genu MECP2 wpływa w odmienny sposób na płeć żeńską i męską. [16] Mutacje MECP2, które powodują klasyczną postać zespołu u kobiet zazwyczaj prowadzą do encefalopatii noworodków płci męskiej oraz śmierci w pierwszym roku życia. Ponadto te same dysfunkcje mogą wywołać zespół Klinefeltera (47, XXY) lub mozaikowatość somatyczną. Wreszcie, niektóre mutacje MECP2, które nie powodują widocznych zmian u kobiet, mogą być przyczyną różnego rodzaju chorób u mężczyzn: afektywnej choroby dwubiegunowej, niepełnosprawności intelektualnej z upośledzeniem motoryki [25], schizofrenii młodzieńczej [26]. Zgodnie z wynikami badań Chahrour M. i wsp., nadekspresja genu MECP2 u płci męskiej może doprowadzić do niespecyficznej, ciężkiej niepełnosprawności intelektualnej. Zatem zaburzenia neurorozwojowe są wynikiem utraty funkcji MeCP2, jednakże zwiększenie stężenia białka MeCP2 może być również szkodliwe dla układu nerwowego [16].

Przyczyną Zespołu Retta, zgodnie z wynikami współczesnych badań, są głównie mutacje de novo, powstające przede wszystkim na chromosomie ojcowskim [1]. Zdarzają się również rodzinne postacie zespołu Retta spowodowane:

- matczyną mozaiką germinalną [4], a także znacznie rzadszą ojcowską mozaikowatością germinalną [8]. Oznacza to, że nieprawidłowe linie komórkowe występują w gonadach, natomiast kariotyp komórek krwi jest prawidłowy. Ten rodzaj mozaikowatości występuje prawdopodobnie u par, których dzieci mają taką samą aberrację chromosomową.

- ukierunkowaną, nieselektywną inaktywacją matczynego chromosomu X, oraz rzadziej występującą inaktywacja selektywną [9].
W jednej linii są obecne komórki $\mathrm{z}$ aktywnym chromosomem X i zmutowanym genem MECP2 powstałym $\mathrm{w}$ czasie inaktywancji partnerskiego chromosomu $\mathrm{X}$. Natomiast druga linia zawiera komórki $\mathrm{z}$ aktywnym chromosomem $\mathrm{X}$ i niezmutowanym genem MECP2. Przyczynia się to do somatycznej mozaikowatości komórek u dziewczynek z zespołem Retta. Inaktywacja chromosomu X $\mathrm{z}$ pary homologicznych chromosomów $\mathrm{X}$ jest $\mathrm{w}$ większości przypadków losowa.

Niezbyt często występującym zaburzeniem jest inaktywacja selektywna. W zależności od preferowanego chromosomu X obserwujemy różny fenotyp u dziewczynek z zespołem Retta. Przykładem mogą tu być bliźnięta monozygotyczne charakteryzujące się różnorodnym przebiegiem choroby [14]. Ponadto badania Young I., Zoghbi H.Y. wskazują na zależność pomiędzy stopniem selektywności w inaktywacji chromosomu X, a rodzajem objawów klinicznych oraz ich ciężkością na przykładzie myszy transgenicznych [15].

Zgodnie z wynikami badań Villard L.i in., zdarzają się sytuacje, w których fenotyp zespołu Retta występuje bez mutacji w genie $M E C P 2$, i zawiera pełną selektywną formę dziedziczenia inaktywacji chromosomu X [10].

Kolejnym genem uczestniczącym w etiopatogenezie zespołu Retta jest $\boldsymbol{C D K L 5 ( S T K 9 ) . ~ J e s t ~ t o ~ m u t a c j a ~ z m i a n y ~}$ sensu odczytu i mutacja odcinająca w genie (OMIM*300203) [3], który jest zlokalizowany w locus Xp22, jak też koduje cyklozależną kinazę 5 (ang. cyclin-dependent kinase like 5), nazywaną również kinazą 9 seryno-treoninową (ang. serine/threonine protein kinase 9). Zgodnie z piśmiennictwem geny MECP2 oraz CDKL5 uczestniczą w tym samym szlaku sygnałowym i posiadają zdolność do autofosforylacji [13]. Większość mutacji dotyczących genu CDKL5 występuje u kobiet, jedynie sporadycznie spotykane są u mężczyzn. Na skutek tej mutacji powstaje fenotyp zespołu Retta zwany podtypem Hanefelda [1]. Charakterystyczne dla niego są występujące już w okresie noworodkowym napady zgięciowe. Towarzyszą mu również epilepsja oraz upośledzenie umysłowe w stopniu ciężkim.

$\mathrm{Na}$ podstawie opublikowanych wyników badań, zmiany cytogenetyczne takie jak zrównoważona translokacja chromosomowa $\mathrm{t}(2 ; 14)$ (p22;q12) de novo oraz dodatkowa inwersja wielkości $720-k b p$ w regionie punktu złamania 14q12, doprowadzają do uszkodzenia genu FOXG1 (ang. Forkhead BoxG1) (OMIM+164874) [3] w regionie końca 5'. Gen ten odpowiada za alternatywne składanie pierwotnego transkryptu w wyniku czego powstaje białko wariantowe. W piśmiennictwie odnotowano przypadek dziewczynki z opóźnionym rozwojem umysłowym, agenezją ciała modzelowatego i małogłowiem. Po upływie dwóch tygodni od urodzenia wystąpiła u niej spastyczność mięśniowa w stopniu dużym. Natomiast nabyte małogłowie zostało zauważone w wieku 6 
miesięcy, gdy jeszcze nie unosiła głowy. Ponadto w wieku 7 lat wystąpił paraliż czterokończynowy, pacjentka nie potrafiła samodzielnie chodzić, siedzieć ani mówić, wystąpiły u niej drgawki [5]. U kolejnych, dwóch niespokrewnionych dziewczynek z nabytym małogłowiem, stereotypią ruchową i opóźnionym rozwojem umysłowym, zostały również zidentyfikowane dwie odmienne heterozygotyczne mutacje genu FOXG1[6]. Powyższe badania świadczą o tym, że mutacje genu FOXG1 mogą przyczyniać się do powstawania fenotypu charakterystycznego dla zespołu Retta.

W literaturze jako czynnik etiologiczny podawane są też mikrodelecje (nukleotydy 1030 i 1207) i mikroduplikacje regionów krytycznych dla zespołu Retta [11]. To mikrodelecje genu MEF2C (ang. Myocyte-specific Enhancer Factor-2/ Mads Box Transcription Enhancer Factor 2, polypeptide c) (OMIM, *600662) [3] powodują obniżenie stężenia białka MeCP2 oraz CDKL5. Białko to odpowiedzialne jest za programowanie wczesnego różnicowania neuronów, a także odpowiednią dystrybucję $\mathrm{w}$ korze nowej. W piśmiennictwie zostały opisane cztery przypadki mutacji tego genu u pacjentów z atypową formą zespołu Retta.

Istnieje prawdopodobieństwo, że mutacje genu NTNG1 (ang. G1) (OMIM*608818) [3], są także odpowiedzialne za powstawanie fenotypu swoistego dla zespołu. Borg I. i wsp. opisali przypadek dziewczynki, u której zidentyfikowano translokację chromosomową pomiędzy chromosomami 1 i 7. Przeprowadzone badania wykazały, że na chromosomie 1 została przerwana ciągłość genu NTNG1, natomiast ciągłość genów na chromosomie 7 była zachowana [7]. Zgodnie z piśmiennictwem, netryna wykazując ekspresję, bierze udział w rozwoju mózgu, dlatego istnieją przypuszczenia odnośnie jej udziału w powstawaniu Zespołu Retta .

Wbrew wcześniejszym teoriom, które uznawały białko MeCP2 za uniwersalnego represora transkrypcji, Chahrour wraz ze współpracownikami dowiódł, że MeCP2 znacznie częściej pełni funkcję aktywatora genów docelowych. Co więcej, białko MeCP2 może w różnym stopniu aktywować ekspresję danego genu. Zależy to bowiem od stopnia metylacji promotora genu podległego białku MeCP2. Jeżeli jest słabiej zmetylowany, to wówczas MeCP2 działa jako aktywator ekspresji. Natomiast jest represorem, jeśli metylacja promotora jest silniejsza. Zatem zgodnie $\mathrm{z}$ wynikami powyższych badań białko MeCP2 należy uznać za czynnik kontrolujący ekspresję danych genów.

Białko MeCP2 pełni również kluczową rolę $\mathrm{w}$ synaptogenezie. Wraz $\mathrm{z}$ CREB1 bierze udział w zachowaniu plastyczności nerwowej. MeCP2 indukuje aktywność CREB1, z kolei CREB1 hamuje syntezę białka MeCP2. Białka te są fosforylowane podczas aktywacji neuronów i mogą wpływać na geny aktywowane podczas tworzenia się synaps. W wyniku mutacji prowadzącej do niedoboru MeCP2 liczba pobudzonych synaps jest zmniejszona. Zgodnie $\mathrm{z}$ piśmiennictwem, u dziewcząt z zespołem Retta zaobserwowano zmiany dotyczące zmniejszenia rozmiarów komórek nerwowych i redukcji gęstości kolców dendrytycznych. Ponadto istnieją dowody, że spadek gęstości kolców dendrytycznych i obniżenie syntezy białek presynaptycznych w hipokampie (w modelu mysim) jest spowodowany nieprawidłową funkcją MeCP2.

Zaburzenia oddychania występujące w zespole mogą być również spowodowane niedoborem białka MeCP2, decydującym o nieprawidłowym rozwoju układu nerwowego u chorych. Możliwe, że jest to wywołane osłabieniem układu noradrenergicznego, niedojrzałością pnia mózgu czy nieprawidłowym funkcjonowaniem kory mózgowej. Ponadto przeprowadzone na zwierzętach badaniach udowodniły, iż wraz z wiekiem dochodzi do zmniejszenia syntezy białka BDNF. Białko to jest regulatorem aktywności synaptycznej układu autonomicznego w pniu mózgu i czaszkowych zwojach czuciowych. Poza tym BDNF także chroni mózg przed niedotlenieniem, ponieważ jest jednym z czynników reagujących na stres oksydacyjny. Zatem białko MeCP2 poprzez działanie na gen $b d n f$ pełni bardzo ważną rolę w homeostazie krążeniowo-oddechowej.

Dodatkowo wykazano, że białko MeCP2 bierze udział w reakcji organizmu na stres, bowiem zwiększa ono ekspresję genów odpowiedzialnych za regulację syntezy glikokortykosteroidów. Między innymi McGill wraz ze współpracownikami badał fizjologiczną reakcję w odpowiedzi na stres u mysz z mutacją Mecp2308. Badania te wykazały wzrost stężenia kortykosteronu oraz ekspresji genu $\mathrm{Crh}$, spowodowany nieprawidłowościami białka MeCP2. W odpowiedzi na stres u mysz pozbawionych genu Mecp2, spowodowany zmienioną ekspresją genu sim1, podwyższonym stężeniem leptyny, melanokortyny, neuropeptydu Y oraz białka arc. zaobserwowano wzrost łaknienia. Niewykluczone, że rozwój otyłości u dziewczynek z zespołem Retta ma taki sam patomechanizm.

Białko MeCP2 reguluje także bezpośrednio ekspresje wielu genów, tj. Bdnf, mef2c, Sgk1, Uqcrc1 czy $D L X 5$, etc. Białko kodowane przez gen Bdnf, mózgowy czynnik wzrostu, kontroluje dojrzewanie neuronów, opowiada za plastyczność neuronalną oraz funkcje oddychania. Natomiast produkt genu Sgk1 jest regulatorem szlaku glikokortykosteroidów w osi podwzgórze-przysadka. Z kolei białko kodowane przez gen mef2c to polipeptydowy czynnik transkrypcyjny miocytów. Geny Uqcrc1 oraz DLX5 kodują odpowiednio mitochondrialny regulator reakcji oddechowej i neuronalny czynnik transkrypcyjny. Produkty tych genów mają duże znaczenie funkcjonalne $\mathrm{w}$ organizmie 
oraz odpowiadają za charakterystyczny fenotyp zespołu. Niezmiernie ważna jest identyfikacja tych produktów, ponieważ to od niej zależy decyzja dotycząca rodzaju wdrażanej terapii u chorych z zespołem Retta [1].

\section{Obraz kliniczny}

Zespół Retta może występować bez mutacji MECP2 lub może z nimi współwystępować, stanowi więc przede wszystkim diagnozę kliniczną. Zespół ten składa się z szeregu współwystępujących objawów ze strony różnych układów. Zaburzenia występujące w obrębie układu nerwowego, żołądkowo-jelitowego oraz szkieletowego uniemożliwiają dzieciom prawidłowy rozwój. Z kolei charakterystyczne cechy zachowania dzieci z zespołem Retta spowodowały, że dziewczynki dotknięte tym zaburzeniem genetycznym są nazywane Milczącymi Aniołami. Dziewczynki z zespołem Retta wykonują ruchy stereotypowe, ich czas reakcji jest wydłużony, a w stosunku to otoczenia cechują się wyalienowaniem. Dzieci $\mathrm{z}$ zespołem są często diagnozowane jako niesprawne umysłowo, ale diagnozy te są kwestionowane. Ponieważ konwencjonalne testy inteligencji są zazwyczaj oparte na umiejętnościach językowych, wymagają też posługiwania się dłońmi, czyli dwóch najsłabszych cechach osób z zespołem Retta [54].

Zgodnie z piśmiennictwem, u chorych z zespołem Retta obserwuje się przede wszystkim zmiany w układzie ruchu. Osteoporoza oraz zmiany w obrębie kręgosłupa i stóp są podstawowym problemem osób z zespołem. Toteż zgodnie z wynikami opublikowanych w literaturze badań, skolioza występuje u 100\% niechodzących i 36-64\% chodzących dziewcząt. Powoduje ona nie tylko zaburzenia bólowe czy zaburzenia równowagi, ale dodatkowo zaburzenia oddechowe, tj. hiperwentylacja, bezdech, wstrzymywanie oddechu czy wymuszone wypuszczanie powietrza i śliny [45]. Kolejnym objawem klinicznym zespołu Retta są niewielkie stopy u dziewcząt, oprócz tego stopy są zimne, marmurkowate oraz hipotroficzne. Co więcej, charakterystyczny jest spadek masy ciała (BMI - 17,5) i wolne tempo wzrostu występujące u 85-90\% osób z zespołem Retta, postępujące wraz z wiekiem [54].

Typowe są również zaburzenia przewodnictwa przedsionkowo-komorowego i śródkomorowego, tj. tachykardia, wydłużony odstęp QT, bradykadia zatokowa i nieprawidłowy załamek T. Zespół Retta charakteryzuje się także niespecyficznymi zaburzeniami wchłaniania oraz zaburzeniami związanymi z refluksem żołądkowoprzełykowym [52]. W zespole Retta poważny problem stanowią występujące napady padaczkowe, głównie częściowe złożone i toniczno-kloniczne oraz nieprawidłowości w zapisie EEG. Napady padaczkowe występują u 85-50\% kobiet [53], po okresie dojrzewania mają tendencję do zmniejszania stopnia nasilenia aż do niewielkiego w dorosłości. W badaniu grupy 91 osób z zespołem stwierdzono obniżony poziom nastroju, jednak w porównaniu z grupą kontrolną nie były to różnice istotne statystycznie. Natomiast epizody autoagresji były rzadsze w zespole Retta, niż u osób z grupy kontrolnej [49].

Z uwagi na zróżnicowany obraz kliniczny schorzenia w literaturze przedmiotu opisane są trzy postacie zespołu Retta, postać klasyczna, nietypowa oraz postać z zachowaną mową[55]. Postać klasyczna zespołu charakteryzuje się 4 fazami choroby, a spektrum objawów klinicznych zespołu zmienia się wraz $\mathrm{z}$ wiekiem. Niemowlęta początkowo rozwijają się podobnie jak ich zdrowi rówieśnicy [56] często są spokojne, mało płaczą i dużo śpią. Pierwsze zauważalne objawy pojawiają się zwykle w 6-18 miesiącu życia. W tym okresie obserwuje się również spowolniony przyrost obwodu główki, dziecko wykazuje mniejsze zainteresowanie zabawkami, rzadziej nawiązuje kontakt wzrokowy, nieraz występuje też hipotonia mięśni $[48,54]$. Jest to pierwsza faza postaci klasycznej zespołu Retta.

Następnie nadchodzi okres stagnacji i regresji, okres zahamowania rozwoju dziecka. Trwa on najczęściej od 1 do 4 roku życia [57]. Wtedy rozwijające się dotąd normalnie dziecko z dnia na dzień traci kontakt $\mathrm{z}$ otoczeniem, staje się apatyczne, ciche, nie interesuje się zabawkami. Dziecko traci podstawowe umiejętności, zwane kamieniami milowymi, które zostały nabyte w okresie niemowlęcym. Siedzenie, chodzenie oraz zdolności manualne (np. chwytanie) stopniowo zanikają [58].

Utrata kontroli nad własnym ciałem i umysłem prowadzi zazwyczaj do frustracji, gniewu, smutku, strachu i zaskoczenia, jak również poczucia straty. Następnie dziecko wycofuje się emocjonalnie, staje się apatyczne [54].

Celowe ruchy rąk są zastępowane przez powtarzające się ruchy stereotypowe, tj. klaskanie dłoni, ruchy przypominające mycie rąk, pranie, wykręcanie, dotykanie twarzy i głowy, wkładanie do buzi itp. Jest to zazwyczaj jeden z pierwszych niepokojących objawów skłaniających rodziców do wizyty u specjalisty. Zgodnie z piśmiennictwem, to stereotypowe ruchy są jednym z najbardziej istotnych kryteriów diagnostycznych zespołu.

$\mathrm{U}$ wielu dzieci z zespołem $\mathrm{w}$ drugiej fazie schorzenia pojawiają się również zaburzenia oddychania wstrzymywanie bądź połykanie powietrza, hyperwentylacja oraz zgrzytanie zębami (bruksizm), które ustępują podczas snu. Występują też zaburzenia rytmu sen - czuwanie, nocne napady nieuzasadnionego płaczu lub śmiechu [49]. Labilność emocjonalna jest związana $\mathrm{z}$ takimi dolegliwościami fizycznymi, jak: zaparcia, hiperwentylacja, bóle jelit, nadmiar bodźców i zmiana temperatury [54]. Literatura wskazuje na 
występowanie okresów nadmiernego pobudzenia osób $\mathrm{z}$ zespołem Retta, które mogą być wyrazem negatywnych emocji czy nieakceptowanych zmian $\mathrm{w}$ otoczeniu [48]. Z kolei nadaktywność i impulsywność zgodnie z wynikami badań Cianfaglione R. i in., nie są charakterystyczne dla zespołu.

W ciągu kilku tygodni lub miesięcy następuje opóźnienie rozwoju motorycznego. W badaniach Nomury Y. i Segawy M. w grupie 130 osób z RTT 83,3\% wykazywało opóźnienia w opanowaniu umiejętności chodzenia, $63,6 \%$ - raczkowania, $42 \%$ - siadania. W drugiej fazie choroby obecna była również hipertonia mięśniowa. Nierzadko obecne są pierwsze napady drgawkowe, które mogą być objawem epilepsji [48]. Pogarszają się kontakty społeczne i występują zachowania autystyczne oraz zaburzona reakcja na ból, objawy te często mylone są $\mathrm{z}$ autyzmem. Zauważalna jest znaczna utrata więzi emocjonalnej między dzieckiem a rodzicami. Nawet komunikacja z dzieckiem za pomocą gestykulacji i wzroku jest coraz gorsza, zatem kontakt z nim jest bardzo utrudniony. Pod koniec tego etapu dochodzi do częściowego odzyskania równowagi emocjonalnej, które polega między innymi na spokojniejszym usposobieniu dziecka [54].

Trzecia faza choroby, zwana etapem pozornej stagnacji, trwa od około 2 do 10 roku życia. Wciąż obecne są problemy ruchowe i padaczka. Motoryka chorego stale ulega pogorszeniu (apraksja lub ataksja), obserwowalny jest wzrost napięcia mięśniowego. Pojawiają się problemy z układem kostnym (skolioza, deformacje kostek i stóp). Pomimo tego zauważalna jest poprawa kontaktów społecznych i emocjonalnych dziecka, które staje się spokojniejsze i mniej płaczliwe. Występuje na tym etapie silna potrzeba poznawania świata [48]. Niestety z czasem dzieci ponownie manifestują cechy autystyczne, tj. nadwrażliwość na dźwięki, tracą umiejętność wyrażania emocji, są niezdolne do utrzymania kontaktu wzrokowego [58].

Dorośli, będący w ostatniej - czwartej fazie choroby, mają problemy z poruszaniem się. Charakterystyczne dla tej fazy są zaniki mięśni, spastyczność oraz pogłębienie się skoliozy. Większość kobiet, które do tego momentu chodziły, traci tę umiejętność. Aczkolwiek rzadziej występują napady padaczkowe i stereotypowe ruchy rąk. Dodatkowo następuje poprawa kontaktu emocjonalnego i wzrokowego [48]. Zgodnie z badaniami Lane J. i in., osoby charakteryzujące się gorszym stanem klinicznym, zwykle lepiej funkcjonują psychospołecznie [51]. Z kolei w późnej fazie choroby u osób z zespołem Retta mogą występować cechy parkinsonizmu i napadowego [59].

Natomiast postać nietypowa zespołu Retta cechuje się brakiem okresu prawidłowego rozwoju. Ma ona znacznie cięższy przebieg niż postać klasyczna [60]. Opóźnienie jest zazwyczaj zauważane niedługo po narodzinach dziecka, nie jest obecna więc faza normalnego rozwoju dziecka, podobnie jak nie ma fazy regresu [48]. Dla tej postaci charakterystyczne są napady zgięciowe oraz wrodzona hipotonia mięśniowa.

Z kolei trzecia postać zespołu Retta - postać z zachowaną mową - występuje u 1-4\% wszystkich osób z zespołem Retta i wyróżnia się późnym początkiem choroby [60]. Charakterystyczna jest stopniowa regresja, która rozpoczyna się po trzecim roku życia [54]. Według Marschika P. i in. wśród dzieci z zachowaną mową, również występują zaburzenia społecznokomunikatywne, które są obecne jeszcze przed okresem regresji [50].

\section{Podstawowe kryteria diagnostyczne zespołu Retta}

Zgodnie $\mathrm{z}$ obowiązującą $\mathrm{w}$ chwili obecnej klasyfikacją ICD-10 rozpoznanie zespołu Retta opiera się na następujących kryteriach:

1. Przebieg okresu prenatalnego i okołoporodowego jest pozornie normalny.

2. W ciągu pierwszych 5 miesięcy rozwój psychomotoryczny jest ogólnie prawidłowy lub jest opóźniony od urodzenia.

3. Obwód głowy dziecka w chwili urodzenia odpowiada obowiązującym normom. Zwolnione jest tempo przyrostu obwodu głowy pomiędzy 5 miesiącem a 4 rokiem życia.

4. Utrata wcześniej nabytych umiejętności celowych ruchów rąk pomiędzy 6 a 30 miesiącem życia. W zamian występują stereotypowe ruchy rąk (np. kręcenie, ściskanie, stukanie opuszkami, klaskanie, mycie).

5. Zaburzona jest komunikacja $\mathrm{z}$ otoczeniem, ujawnia się upośledzenie interakcji społecznych, dysfunkcje poznawcze. Zaburzone są także ekspresja i rozumienie języka.

\section{Farmakoterapia}

W ciągu ostatnich kilku lat pojawiły się doniesienia dotyczące funkcji MeCP2, podobnie jak konsekwencji utraty tego białka, rozpoczęte zostały prace nad potencjalnymi strategiami terapeutycznymi zespołu Retta [28-33]. Należą do nich m.in.: molekularne metody genetyczne, aktywacja allelu „the wild-type" na nieaktywnym chromosomie X oraz znajdujące się na etapie badań klinicznych metody farmakologiczne, mające na celu przywrócenie równowagi pobudzająco-hamującej w układzie nerwowym. Celem powyższych strategii jest przede wszystkim normalizacja ekspresji genu MECP2 bez wpływu na produkty innych genów. Zarówno w przypadku terapii genowej jak i aktywacji allelu "the wild-type" na nieaktywnym chromosomie X istotne jest doprowadzenie do wytworzenia w komórce wystarczającej ilości białka MeCP2 przy jednoczesnym powstrzymaniu nadmiernej ekspresji MECP2. 


\section{Aktywacja MECP2 na nieaktywnym chromosomie X}

Zgodnie $\mathrm{z}$ wynikami badań opublikowanych dotychczas w literaturze, większość mutacji prowadzi do wytworzenia niefunkcjonalnego białka MeCP2. Zatem reaktywacja "the wild-type" na nieaktywnym X w tym podejściu może być przydatna do leczenia wielu postaci Zespołu Retta. Ponadto w badaniach Meng, L.i in. została wykazana wartość terapeutyczna reaktywacji genów chorobowych u myszy $\mathrm{z}$ Zespołem Angelmana. $\mathrm{W}$ powyższym badaniu uśpiony gen Ube3a (ale nieuszkodzony) został farmakologicznie aktywowany, aby zastąpić zmutowany gen Ube3a [34] [35]. Poza tym gen reporterowy, czyli gen wizualizujący Mecp2-GFP jest cennym narzędziem do oceny aktywacji alleli MeCP2. Wyniki przeprowadzonych badań potwierdzają, że istnieje możliwość reaktywacji całego nieaktywnego X (XI). Ostatnie prace wykazały, że utrata hormonu białkowego, Stanniocalcin 1 (STC1), zakłóca proces wyciszania ekspresji genów sprzężonych z chromosomem X, w tym Mecp2. Tym samym, podejście to może wydawać się mniej atrakcyjne [36].

Z kolei badania przeprowadzone przez Adriana Birda z Uniwersytetu w Edynburgu, dowodzą, że w wyniku podania białka MECP2 myszom ze zmutowanym genem, dochodzi do odwrócenia zmian w uszkodzonym mózgu, tym samym do przywrócenia właściwego funkcjonowania organizmu. W perspektywie powyższych badań nad rozwojem terapii uszkodzonego białka MECP2, istnieje więc szansa na wyeliminowanie objawów choroby także u dzieci i dorosłych z zespołem Retta [48].

\section{Terapia genowa}

Kolejną metoda mającą na celu przywrócenie funkcji MeCP2 polega na zastępowaniu wadliwego genu lub korekcji uszkodzonych genów. Zgodnie z wynikami najnowszych badań, za pomocą rekombinowanego wektora adenowirusowego (AAV9) jest możliwy transfer genów w całym układzie nerwowym [37] [38] [39]. U myszy z modelem zespołu Retta, pozbawionych genu MECP2, po dożylnym podaniu wektora AAV9 / MECP2 doszło do częściowego znormalizowania behawioralnego i fenotypowego oraz przedłużenia życia [40] [41]. Wyzwaniem terapii genowej jest więc dostarczanie MECP2 w wąskim zakresie, tj. terapeutycznym, bez powodowania szkodliwej nadekspresji. Mimo iż wektor dostarcza MECP2 do mózgu, to w wątrobie dochodzi do ok. 100-krotnie wyższego transferu genów, co działa toksycznie [40].

\section{Cele terapeutyczne}

Prowadzone są badania przedkliniczne dotyczące potencjalnych leków, które mogą być skuteczne w złagodzeniu specyficznych objawów chorobowych u osób z zespołem Retta. Leki te zostały podzielone na trzy kategorie obejmujące:

1. Modyfikację neuroprzekaźnictwa noradrenergicznego, serotoninergicznego, glutaminergicznego, GABAergicznego i cholinergicznego;

2. Czynniki wzrostu: neurotroficzny czynnik pochodzenia mózgowego (BDNF) i insulinopodobny czynnik wzrostu 1 (IGF-1);

3. Szlaki metaboliczne, w tym szlak biosyntezy cholesterolu i szlaki mitochondrialne [28] [29] [31] [44]

Ponadto istnieją doniesienia z kilku laboratoriów, że zaburzenia oddechowe u myszy z modelem zespołu Retta można znacznie poprawić poprzez modyfikację neuroprzekaźników w tym glutaminergicznych, GABAergicznych, noradrenergicznych, serotoninergicznych [45] [46].

Naukowcy zbliżają się do zrozumienia podstaw biologii MeCP2 i istnieje coraz więcej przykładów działań, które poprawiają lub odwracają objawy u mysich modeli z zespołem Retta.

\section{Inne formy terapii zespołu Retta}

Na przykładzie wyników wielu badań dotyczących leczenia całościowych zaburzeń rozwojowych (w tym zespołu Retta) zalecana jest wczesna interwencja oraz długoterminowa terapia indywidualna. W większości krajów zachodnich prawo nakazuje realizację odpowiedniego planu edukacyjnego dla wszystkich dzieci, $\mathrm{w}$ tym dzieci specjalnej troski. $\mathrm{W}$ ramach tego programu często dodatkowo uwzględniana jest terapia logopedyczna, fizjoterapia, terapia zajęciowa czy inne formy terapii [53].

Objawy kliniczne zespołu Retta są bardzo złożone. W pierwszym roku życia zespół Retta jest najczęściej mylony $\mathrm{z}$ mózgowym porażeniem dziecięcym, w późniejszym okresie z autyzmem. Ponieważ w pierwszych fazach rozwoju zespołu Retta nie ujawniają się wszystkie charakterystyczne objawy zaburzenia, wielokrotnie dochodzi do nieprawidłowego rozpoznania jednostki chorobowej. Istotną rolę we wczesnym rozpoznaniu zespołu Retta pełni pediatria, gdyż ważna jest szybka diagnostyka dziecka z podejrzeniem tego zaburzenia.

Niezwykle istotne jest profesjonalne informowanie rodziców o rozpoznaniu. Dostarczanie rzetelnej informacji $\mathrm{w}$ celu poszerzenia ich wiedzy na temat choroby i podawanie konkretnych wskazówek, gdzie mogą szukać pomocy [48]. Należy skierować pacjenta do zespołu diagnostycznego, który określi jego rozwój fizyczny, psychiczny i emocjonalny. Zatem termin "wczesna interwencja" obejmuje pierwotną diagnozę, terapię dziecka oraz wsparcie rodziców. Ponadto obejmuje opiekę wielospecjalistyczną, mającą na celu wspomaganie rozwoju ruchowego dziecka, a także 
zapobieganie pojawieniu się wtórnych dysfunkcji życiowych. W terapii zespołu Retta stosuje się fizykoterapię, muzykoterapię, hydroterapię, hipoterapię, metody behawioralne, logopedię oraz dietę specjalistyczną.

Dzieci z zespołem wymagają stałej opieki pediatrycznej, neurologicznej i ortopedycznej. W monitorowaniu przebiegu zespołu Retta należy kontrolować rozwój psychoruchowy i somatyczny, stan odżywienia, umiejętności motoryczne oraz kontakty w środowisku międzyludzkim. Szczególny nacisk kładzie się na rehabilitację ruchową, która obejmuje ćwiczenia ogólnorozwojowe, ponieważ osoby te borykają się z całym wachlarzem problemów, począwszy od trudności ortopedycznych i neurologicznych. Pokonywanie ograniczeń związanych $\mathrm{z}$ nimi jest zadaniem niezwykle trudnym dla osoby $\mathrm{z}$ zespołem Retta i jej rodziny. Zatem praca z fizjoterapeutą może poprawić sprawność, a tym samym zmniejszyć negatywne konsekwencje braku aktywności fizycznej dziecka [53].

Natomiast muzykoterapia wykorzystując potencjalnie ukryte zdolności osób z zespołem, stwarza im możliwość wyrażania własnych emocji i uczuć, tym samym sprzyja komunikacji interpersonalnej. Już Andreas Rett dostrzegał w muzyce ogromny potencjał, pozwalający przeniknąć przez barierę niepełnosprawności osób z zespołem Retta. Zgodnie z aktualnym stanem wiedzy, muzykoterapia poprawia motorykę małą oraz zmniejsza stereotypowe ruchy rąk. Metoda ta pozwala rozwijać artykulację, poprawia koncentrację uwagi i kontaktu wzrokowego oraz pozytywnie wpływa na rozwój emocjonalno-komunikacyjny.

Większość osób z zespołem Retta ma trudności z językiem mówionym, lecz uważa się, że ich zdolność do rozumienia języka jest znacznie wyższa, niż zdolność do mówienia [53]. Dziewczynki z zespołem Retta mają duże problemy w nawiązywaniu kontaktu z otoczeniem. Większość z nich nie porozumiewa się za pomocą mowy, lecz gestów i mimiki. Komunikacja jest możliwa dzięki wprowadzaniu alternatywnych, choćby najprostszych form komunikowania, np. obrazków, piktogramów czy systemu "tak-nie". Dobrym przykładem jest trening komunikacyjny (FCT) [51], także program oparty o teorię rozwoju Piaget'a z elementami metody Domana-Delacato. Program obejmuje m.in. komunikację alternatywną za pomocą symboli PCS [48].

$\mathrm{Z}$ kolei funkcje manualne wspomaga się poprzez różne formy terapii zajęciowej.

Pacjentki te mają zaburzone funkcje poznawcze, nie są $\mathrm{w}$ stanie wykonywać ruchów precyzyjnych, gdyż utrudnia im to apraksja. Osoby z zespołem mają trudności w wykonywaniu czynności życia codziennego (jedzenie, samoobsługa), mają zaburzone planowanie ruchu, dlatego potrzebują więcej czasu na wykonanie zleconego zadania. Terapeuta może pomóc osobie z zespołem Retta, wykorzystując metodę „integracji sensorycznej”, łączącej informacje z receptorów wszystkich zmysłów (dotyk, kołysanie itp.) potrzebne do celowego i efektywnego działania.

Tymczasem hydroterapia jest pomocna w redukcji spastyczności. Osoba z zespołem Retta osiąga zdolność do działania, którego nie potrafi wykonać będąc na lądzie. Jest w stanie łatwo i swobodnie poruszać się w wodzie bez obawy przed upadkiem. Ponadto hydroterapia daje też szansę na nawiązanie przez dziecko bardziej satysfakcjonujących relacji z rówieśnikami $[48,53]$.

O skuteczności terapii decyduje między innymi współpraca z rodzicami pacjentek, stojącymi przed koniecznością sprostania różnorodnym wyzwaniom np. utratą kolejnych umiejętności dziecka. Rodziny powinny być wspomagane $\mathrm{w}$ podejmowaniu świadomych decyzji dotyczących stosowania alternatywnych metod leczenia, rehabilitacji, interwencji chirurgicznych, wyboru specjalistów, edukacji [53]. Trzeba nauczyć ich wyrażać emocje, wspierać w tworzeniu silnej więzi emocjonalnej z dzieckiem. Ze względu na zmienny charakter zespołu, działania terapeutyczne muszą być elastyczne, dostosowane do sytuacji i potrzeb indywidualnych. Celem interwencji prowadzonej przez terapeutów jest przede wszystkim osiągnięcie najlepszego poziomu funkcjonowania i najwyższej jakości życia przez osoby z zespołem Retta [53].

\section{References:}

1. Midro A. T. Zespół Retta-postępy badań nad patogenezą. Neurologia Dziecięca, 2010; 19(38), 55-63.

2. http://www.ncbi.nlm.nih.gov/gene/4204

3. Online Mendelian Inheritance In Man WWW.nbci.nlm. nih.gov/omim

4. Venancio M., Santos M., Pereria S.A et al.: An explanation for another familial case of Rett syndrome: maternal germline mosaicism. Europ J. Hum Genet 2007; 15: 902-904.

5. Shoichet S.A., Kunde S.A., Viertel P. et al.: Haploinsufficiency of novel FOXG1B variants In a patient with severe mental retadation brain malformations and microcephaly. Hum Genet 2005; 117: 536-544.

6. Ariani F., Hayek G., Rondinella D. et al.: FOXG1 is responsible for the congenital variant of Rett syndrome. Am J Hum Genet 2008; 83:89-93.

7. Borg I., Freude K., Kübart S. et al.: Disruption of Netrin G1 by a balanced chromosome translocation In a girl with Rett syndrome. Eur J Hum Genet 2005; 13: 921-927.

8. Evans J.C., Archer H.L., Whatley S.D. et al.: Germline mosaicism for a MECP2 mutation in a Man with two Rett dauthers. Clin Genet 2006; 70 (4): 336-338.

9. Gill H., Cheadle J.P., Maynard J. et al.: Mutation analysis in the MECP2 gene and genetic counselling for Rett syndrome. J Med. Genet 2003; 40: 380-384.

10. Villard L., Lếvy N., Xiang F. et al.: Segregation of a totally skewed pattern of X chromosome inactivation in four familial cases of Rett syndrome without MECP2 mutation: implications for the disease. J Med Genet 2001; 38 (7): 435-442. 
11. Genetyka medyczna : podręcznik dla studentów / red. Gerard Drewa, Tomasz Ferenc. - Wyd. 1, dodr. - Wrocław : Elsevier Urban \& Partner, cop. 2013; 248-249; 631-632.

12. Olson CO, Zachariah RM, Ezeonwuka CD, Liyanage VR, Rastegar $\mathrm{M}$ : Brain region-specific expression of MeCP2 isoforms correlates with DNA methylation within Mecp2 regulatory elements

13. Bertani I., Rusconi L., Bolognese F. et al.: Functional consequences of mutations In CDKL5, an X linked gene involved In infant ile spasms and mental retardation. J Biol Chem 2006; 281: 32048- 32056

14. Dragich J., Houẃink-Manville C., Schanen N. et al.: Rett Syndrome: a surprising result of mutation in MECP2. Hum Mol Genet 2000; 9: 2365-2375.

15. Young I., Zoghbi H.Y.: X-chromosome inactivation patterns are inbalanced and affect the phenotypic outcome In a Mouse model of rett syndrome. Am J Hum Genet 2004; 74: 511-520

16. Chahrour M, Huda Y. Zoghbi: The Story of Rett Syndrome: From Clinic to Neurobiology.

17. Kerr, A.M., Archer, H.L., Evans, J.C., Prescott, R.J., and Gibbon, F.: People with MECP2 mutation-positive Rett disorder who converse; J. Intellect. Disabil. Res. 2006; 50: 386-394.

18. Leonard, H., Colvin, L., Christodoulou, J., Schiavello, T., Williamson, S., Davis, M., Ravine, D., Fyfe, S., de Klerk, N., Matsuishi, T. et al.: Patients with the R133C mutation: is their phenotype different from patients with Rett syndrome with other mutations?; J. Med. Genet. 2003; 40: e52

19. Neul, J.L., Fang, P., Barrish, J., Lane, J., Caeg, E., Smith, E.O., Zoghbi, H., Percy, A., and Glaze, D.G.: Specific mutations in methyl-CpGbinding protein 2 confer different severity in Rett syndrome; Neurology. 2007.

20. Bienvenu, T. and Chelly, J.: Molecular genetics of Rett syndrome: when DNA methylation goes unrecognized; Nat. Rev. Genet. 2006; 7: 415-426.

21. Milani, D., Pantaleoni, C., D'Arrigo, S., Selicorni, A., and Riva, D.: Another patient with MECP2 mutation without classic Rett syndrome phenotype; Pediatr. Neurol. 2005; 32: 355-357

22. Watson, P., Black, G., Ramsden, S., Barrow, M., Super, M., Kerr, B., and Clayton-Smith, J.: Angelman syndrome phenotype associated with mutations in MECP2, a gene encoding a methyl CpG binding protein; J. Med. Genet. 2001; 38: 224-228

23. Carney, R.M., Wolpert, C.M., Ravan, S.A., Shahbazian, M., AshleyKoch, A., Cuccaro, M.L., Vance, J.M., and Pericak-Vance, M.A.: Identification of MeCP2 mutations in a series of females with autistic dis order; Pediatr. Neurol. 2003; 28: 205-211

24. Lam, C.W., Yeung, W.L., Ko, C.H., Poon, P.M., Tong, S.F., Chan, K.Y., Lo, I.F., Chan, L.Y., Hui, J., Wong, V. et al.: Spectrum of mutations in the MECP2 gene in patients with infantile autism and Rett syndrome; J. Med. Genet. 2000; 37: E41

25. Klauck, S.M., Lindsay, S., Beyer, K.S., Splitt, M., Burn, J., and Poustka, A.: A mutation hot spot for nonspecific X-linked mental retardation in the MECP2 gene causes the PPM-X syndrome; Am. J. Hum. Genet. 2002; 70: 1034-1037.

26. Cohen, D., Lazar, G., Couvert, P., Desportes, V., Lippe, D., Mazet, P., and Heron, D.: MECP2 mutation in a boy with language disorder and schizophrenia; Am. J. Psychiatry. 2002; 159: 148-149.

27. Jan, M.M., Dooley, J.M., and Gordon, K.E.: Male Rett syndrome variant: application of diagnostic criteria; Pediatr. Neurol. 1999; 20: 238-240.

28. Gadalla, K.K, et al. (2011) MeCP2 and Rett syndrome: reversibility and potentai; avenues for therapy. Biochem. J. 439,1-14

29. Lombardi, L.M, et. al. (2015) MECP2 disorders from the clinic to mice and back. J. Clin. Invest. 125, 2914-2923

30. Werg, S.M. et al. Rett syndrome from bed to bench. Pediatr. Neonatol. 2011, 52, 309-316.
31. Pozzo-Miller, L. et al. Rett Syndrome: reaching for clnical trials. Neurotherapeutics 2015, 12, 631-640

32. Ricceri, L. et al. Rett syndrome treatment in mouse models: searching for effective targets and strategies. Neuropharmacology 2013, 68, 106-115

33. Chapleau,C.A. et al. Recent progress in Rett Syndrome and MeCP2 dysfunction: assessment of potential treatment options. Future Neurol. Published online January 1, 2013.

34. Huang, H.S. et al. Topoisomerase inhibitors unsilence the dormant allele of Ube3a in neurons. Nature 2012; 481, 185-189.

35. Meng, L. et al. Towards a therapy for Angelman syndrome by targeting a long non-coding RNA. Nature 2015; 518, 409-412 .

36. Durand, S. et al. NMDA receptor regulation prevents regression of visual cortical function in the absence of Mecp2. Neuron 2012; 76, 1078-1090

37. Gray, S.J. et al. (2011) Preclinical differences of intravascular AAV9 delivery to neurons and glia: a comparative study of adult mice and nonhuman primates. Mol. Ther. 19, 1058-1069

38. Duque, S. et al. (2009) Intravenous administration of self-complementary AAV9 enables transgene delivery to adult motor neurons. Mol. Ther. 17, 1187-1196

39. Foust, K.D. et al. (2009) Intravascular AAV9 preferentially targets neonatal neurons and adult astrocytes. Nat. Biotechnol. 27, 59-65

40. Gadalla, K.K. et al. (2013) Improved survival and reduced phenotypic severity following AAV9/MECP2 gene transfer to neonatal and juvenile male Mecp2 knockout mice. Mol. Ther. 21, 18-30

41. Garg, S.K. et al. (2013) Systemic delivery of MeCP2 rescues behavioral and cellular deficits in female mouse models of Rett syndrome. J. Neurosci. 33, 13612-13620

42. Savic, N. and Schwank, G. (2015) Advances in therapeutic CRISPR/Cas9 genome editing. Transl. Res. Published online September 26, 2015. http://dx.doi.org/10.1016/j.trsl.2015.09.008

43. Deffit, S.N. and Hundley, H.A. (2015) To edit or not to edit: regulation of ADAR editing specificity and efficiency. RNA Pub-lished online November 26, 2015. http://dx.doi.org/10.1002/ wrna.1319

44. Ricceri, L. et al. (2008) Mouse models of Rett syndrome: from behavioural phenotyping to preclinical evaluation of new therapeutic approaches. Behav. Pharmacol. 19, 501-517

45. Ramirez, J.M. et al. (2013) Breathing challenges in Rett Syndrome: lessons learned from humans and animal models. Respir. Physiol. Neurobiol. 189, 280-287

46. Katz, D.M. et al. (2009) Breathing disorders in Rett syndrome: progressive neurochemical dysfunction in the respiratory network after birth. Respir. Physiol. Neurobiol. 168, 101-108

47. Katz, D.M. etal. (2012) Preclinical research in Rett syndrome: setting the foundation for translational success. Dis. Model. Mech. 5, 733-745

48. Kosno D. (2011) Zespół Retta - Zaburzenie Neurorozwojowe o Podłożu Genetycznym "Nieznane? Poznane. - Zaburzenia rozwojowe u dzieci z rzadkimi zespołami genetycznymi i wadami wrodzonymi."Marzeny Buchnat i Pawelczak K, Wyd. UAM Poznań

49. Cianfaglione R., Clarke A., Kerr M., Hastings R.P., Oliver Ch. Et al. (2015), A national survey of Rett syndrome: behavioural characteristics. Journal of Neurodevelopmental Disorders Advancing Interdisciplinary Research 2015 7:11

50. Marschik P., Kaufmann WE, Einspieler C., Bartl-Pokorny K.D., Wolin T., Pini G., Budimirovic D.B., Zappella M., Sigafoos J. (2012) Profiling early socio-communicative development in five young girls with the preserved speech variant of Rett syndrome. Res Dev Disabil. 2012 Nov-Dec; 33(6): 1749-56.

51. Byiers B., Dimian A., Symons F.J. (2014) Functional Communication Training in Rett Syndrome: A Preliminary Study. American Journal on Intellectual and Developmental Disabilities July 2014, Vol. 119, No. 4, pp. 340-350 
52. Lane J.B., Lee H.S., Smith L.W., Cheng P., Percy A.K. et al. Clinical severity and quality of life in children and adolescents with Rett syndrome. Neurology. 2011 Nov 15;77(20):1812-8.

53. Lotan M. Rett Syndrome. Guidelines for Individual Intervention. The Scientific World Journal 2006, 6 (6): 1504-16.

54. Lotan M., Ben-Zeev B. Rett Syndrome. A Review with Emphasis on Clinical Characteristics and Intervention. The Scientific World Journal 2006 (6): 1517-41.

55. Bentkowski Z., Tylki-Szymańska A.: Zespół Retta - aktualny stan wiedzy. Ped. Pol., 1997: 2: 103-112.

56. Pietrykowska A., Patogeneza i rozpoznanie kliniczne zespołu Retta, Journal of Health Sciences, 2014, 4 (1): 401-408.

57. Chahrour M., Huda Y. Zoghbi. The Story of Rett Syndrome: From Clinic to Neurobiology. Figure 1. Onset and Progression of RTT Clinical Phenotypes. Neuron Review, 2007: 423.

58. Nomura Y. Early behavior characteristics and sleep disturbance in Rett syndrome. Brain Dev. 2005, 27 (Suppl 1): 35-S42.
59. Hagberg B. Rett syndrome: long-term clinical follow-up experiences over four decades. J. Child Neurol. 2005, 20: 722-727.

60. Bentkowski Z.A., Tylki-Szymańska A., Jóźwiak S.: Rozpoznanie zespołu Retta w oparciu o własne obserwacje w grupie 100 dziewczynek. Neurologia Dziecięca 2001,10 (19): 9-17.

\section{Correspondence address}

Ewelina Dziwota

Email: dziwota.e@gmail.com

II Klinika Psychiatrii i Rehabilitacji Psychiatrycznej w Lublinie 20-439 Lublin, ul. Głuska 1

Otrzymano: 15.09 .2016

Zrecenzowano: 10.10.2016,03.11.2016

Przyjęto do druku: 07.11.2016 